\section{JĘZYKOWO-KULTUROWY OBRAZ CZASU}

Joanna Szadura, Czas jako kategoria jezykowo-kulturowa w polszczyźnie. Wydawnictwo Uniwersytetu Marii Curie-Skłodowskiej, Lublin 2017, ss. 437.

Książka Joanny Szadury pt. Czas jako kategoria językowo-kulturowa $w$ polszczyźnie ukazała się w roku 2017 nakładem Wydawnictwa Uniwersytetu Marii Curie-Skłodowskiej w Lublinie. We wcześniejszych opracowaniach różnych autorów akcentowane były jedynie wąsko zakreślone zagadnienia dotyczące językowego obrazu czasu w polszczyźnie. Publikacja ta wypełnia zatem istotną lukę w literaturze naukowej: stanowi pierwsze, i w tym sensie w polskiej lingwistyce pionierskie, pełne opracowanie poświęcone bardzo ważnej i złożonej kategorii językowo-kulturowej - CZASU. Praca Joanny Szadury jest godna polecenia jako pozycja dojrzała pod względem metodologicznym, a także bogata i wieloaspektowa ze względu na analizowany materiał językowokulturowy. Przede wszystkim zaś - jest to niezwykle udana próba zmierzenia się $\mathrm{z}$ trudnym wyzwaniem poznawczym, która dzięki rzetelności badawczej autorki oraz jej dociekliwości i pasji zgłębiania różnych obszarów wiedzy, zaowocowała bardzo cennym opracowaniem polskiego sposobu pojmowania czasu.

\section{Problematyka badań}

CZAS jest jedną ze szczególnie istotnych kategorii, organizujących porządek konceptualny języka, a przy tym - kategorią bogatą i złożoną: zarówno uniwersalną (bo występująca u wszystkich ludów świata) jak i zrelatywizowaną kulturowo (dlatego tak ważny jest opis językowo-kulturowego obrazu czasu w polszczyźnie), zarówno obiektywizowaną w ponadkulturowych praktycznych aspektach (w skali globalnej), jak i podatną na wiele przejawów subiektywizmu. Wszystkie wymienione wymiary czasu (i wiele innych) zostały ujęte w monografii J. Szadury. Należy tu zaznaczyć, że omawiana publikacja to efekt wielu lat wytężonej pracy badawczej autorki i bez wahania można stwierdzić, iż monografia ta stanowi jedno z prawdziwych osiągnięć współczesnej polskiej lingwistyki kulturowej.
Badaczka ujmuje zróżnicowane, bogate dane: morfologiczne, składniowe, leksykalne, tekstowe oraz - idąc za sformułowaniem Jerzego Bartmińskiego - wiedze „przyjęzykową" (por. np. Bartmiński 2001). Co istotne, wydobywając bogactwo semantyczne opisywanej kategorii, autorka nie tylko porządkuje i opisuje zgromadzone materiały, ale też stara się dotrzeć do modeli pojęciowych czasu, wyrażanych w polszczyźnie. Przyjmując taką metodę opisu, J. Szadura realizuje istotne założenia lingwistyki kognitywnej, badającej wyrażane w języku sposoby pojmowania świata, a także uznającej gramatykę i leksykę języka za kontinuum semantyczne.

Nawet tak szeroki opis lingwistyczny nie wyznacza jednakże granic problematyki recenzowanej monografii. Warunkiem sine qua non realizacji szeroko zakrojonego projektu badawczego stała się bowiem również bardzo dobra znajomość dotyczącej czasu refleksji filozoficznej, socjologicznej, społeczno-kulturowej, a nawet - wgląd w zagadnienia z zakresu współczesnej fizyki. Bogate interdyscyplinarne zaplecze przedstawionych przez Szadurę badań znacząco wpływa na wysoką wartość merytoryczna, poznawczą publikacji i pozwala sięgnąć do głęboko zakorzenionych w języku, często nieoczywistych motywacji współczesnych znaczeń językowych, odnoszących się do kategorii CZASU.

Co bardzo ciekawe, autorka szeroko omawia kwestię ,rywalizacji” dwóch układów temporalnych, które wyznaczają porządek życia współczesnego człowieka. Są to modele jakościowe (czas biologiczny, słoneczny, agrarny, liturgiczny, polityczny, psychologiczny) oraz model ilościowy, związany z „mierzalnymi” aspektami czasu zegarowego.

Metodologia opisu: ujęcie etnolingwistyczne

Zastosowana metodologia badań wyrasta bezpośrednio z bliskiego autorce ujęcia etnolingwistycznego. Refleksja obejmuje więc nie tylko znaczenia stricte językowe, ale także szeroki wachlarz danych, które za Jerzym Bartmińskim zostały w publikacji określone jako wykładniki „przyjęzykowe”. Joanna Szadura uwzględnia więc materiały 
leksykograficzne, a następnie poszerza pole obserwacji o różne dane tekstowe i wzbogaca analizę o elementy ,wspólnej”, potocznej wiedzy o świecie, która stanowi relewantny poznawczo element komunikacji we wspólnocie językowo-kulturowej. Wiedza ta to zbiór utrwalonych społecznie sądów o świecie, wierzeń, ocen i (często „wchłanianych" nieświadomie) wnioskowań, których przyjęcie stanowi oczywistą bazę komunikacyjną gwarantującą wzajemne zrozumienie członków społeczności.

Monografia zajmuje znaczącą pozycję w dorobku lubelskiego zespołu etnolingwistycznego, którego Joanna Szadura jest członkiem od wielu lat. Co jednak należy podkreślić, autorka recenzowanej tu książki jest badaczką samodzielną i dociekliwą, o dojrzałym warsztacie naukowym i wysokiej świadomości metodologicznej.

\section{Uklad treści}

Publikacja składa się z czterech części, z których dwie pierwsze mają charakter teoretyczno-metodologiczny, zaś dwie kolejne - analityczno-opisowy. Każda z tych części zawiera kilka rozdziałów szczegółowych.

Część pierwsza jest w całości poświęcona pojęciu kategorii. Termin kategoria pojawia się w tytule monografii, autorka postanawia więc szerzej wyjaśnić, jakie znaczenie nadaje tytułowemu sformułowaniu „kategoria językowo-kulturowa”. Dla czytelnika jest to niespodziewane (ze względu na dominujące $\mathrm{w}$ monografii zagadnienie czasu) wzbogacenie lektury o głęboka refleksję sięgającą arystotelesowskiego obiektywizmu poznawczego i subiektywizmu Kanta. Ujęcia te - jako podstawa modeli kategoryzacyjnych - były kontynuowane w obrębie kluczowych paradygmatów naukowych w lingwistyce. Jasny i uporządkowany wywód nie tylko ukazuje punkt wyjścia oraz rozwój refleksji nad kategoryzacją jako procesem poznawczym i zagadnieniem lingwistycznym, ale też pozwala zrozumieć, jaki jest ,punkt dojścia” - czyli sposób, $\mathrm{w}$ jaki czas funkcjonuje $\mathrm{w}$ omawianej publikacji jako kategoria.

Część druga wprowadza zaś czytelnika w zagadnienia dotyczące filozoficznych i socjologicznych koncepcji czasu. Godna podkreślenia jest rzeczowość i dbałość o związek poruszanych zagadnień z zasadniczym tematem publikacji. Autorka przedstawia bowiem te nurty i koncepcje, które pozwalają wyjaśnić ludzkie sposoby rozumienia złożonego i niepoddającego się bezpośredniemu poznaniu zmysłowemu abstraktu, jakim jest czas. Joanna Szadura przypomina więc próby substancjalnego ujęcia czasu (Izaak Newton), koncepcje relacyjne (Arystoteles, Gottfried W. Leibniz), czy teorie socjo-kulturowe (Emil Durkhaim, Aron Guriewicz, Mircea Eliade, Ernest Hall). Dzięki temu czytelnik uświadamia sobie, iż czas choć jest elementem potocznego doświadczenia wszystkich żyjących ludzi - nie ma jednego „wyjaśnienia” - może być różnie konceptualizowany i opisywany. Autorka ukazuje, jak wiele systemów porządkowania czasu wypracowała ludzkość. I tak - za najważniejsze rozróżnienie uznaje podział na systemy jakościowe oraz ilościowe. Wśród tych pierwszych wymienia i charakteryzuje układy reprezentowane przez cykl lunarny i solarny, czas biologiczny, agrarny, liturgiczny czy polityczny. Ilościowe ujęcia czasu opisuje zaś w odniesieniu do miar liczbowych, liczonych za pomoca zegarów w zobiektywizowanym modelu, którego podstawe stanowia godziny, minuty czy sekundy. Szczególnie cenną zdobyczą autorki jest twórcze wykorzystanie strefowej koncepcji czasu Ludwika Bielawskiego (Bielawski 1976) w analizach lingwistycznych o nachyleniu antropologicznym. Jak pisze Szadura: „Wyjściowym założeniem temporalnej teorii Ludwika Bielawskiego jest skonfrontowanie dwóch porządków czasowych - naukowego (obiektywnego - czas istnieje - o ile istnieje, niezależnie od człowieka) i antropologicznego, dla którego podstawowym punktem odniesienia jest człowiek" (Szadura 2017: 83). Przyjęcie perspektywy antropologicznej pozwala dotrzeć do podstaw „ludzkiej skali czasu i przestrzeni" (Bielawski 1976: 222) i analizować jej elementy wyrażane w języku. Ludzkie, naturalne wyczucie czasu, oparte na podstawach biologicznych, somatycznych, fizjologicznych, sprawia, że - jak pisze autorka - „ludzka skala czasu rządzi naszą codziennością" (Szadura 2017: 84).

Trzecia - najobszerniejsza - część monografii jest poświęcona lingwistycznemu ujęciu czasu w polszczyźnie. Składa się ona 
z wielu rozdziałów szczegółowych, w których są omawiane językowe oraz ,,przyjęzykowe" wykładniki kategorii czasu w polszczyźnie. Wykładniki językowe pogrupowane są w obszerne zbiory, kolejno są to: wykładniki leksykalne, morfologiczne i składniowe. Każdy z tych zbiorów danych jest szczegółowo analizowany $\mathrm{i}$ - co bardzo istotne $-\mathrm{z}$ całości wynikają istotne wnioski o charakterze semantycznym, co czyni to ujęcie nowoczesną próbą holistycznego traktowania gramatyki i semantyki. W ostatnim rozdziale tej części autorka analizuje metafory pojęciowe, służące wyrażaniu różnorodnych treści związanych z czasem. Są to między innymi wyobrażenia czasu jako substancji, przedmiotu, istoty żywej czy pojemnika. Autorka analizuje też fundamentalne dla języka modele pojęciowe czasu, takie jak model ruchomego czasu, model ruchomego 'ja' czy model ruchomego czasu cyklicznego.

Ostatnia - czwarta - część książki to analizy etnolingwistyczne prezentujące polskie strefy czasu. Autorka zaczyna od omówienia strefy czasu regulowanej rytmami natury, wyjaśniając w ciekawy i głęboki sposób konceptualizację polskiego tygodnia; następnie - sięgając do prognostyków narodzinowych - zastanawia się nad strefą czasu socjologicznego regulowana rytmem biologicznym życia człowieka. Kolejna strefa to strefa czasu ,płytkiej” historii, która zostaje zilustrowana danymi tekstowymi pochodzącymi z ,epoki gierkowskiej” (lata 70 . XX wieku). Czwarta opisana strefa - czasu historii i tradycji - zostaje omówiona w kontekście różnic $\mathrm{w}$ interpretacji słowiańskiego kalendarza, utrwalonych w tradycji Słowian Zachodnich i Wschodnich (Slavia Latina i Slavia Orthodoxa).

$\mathrm{Na}$ uwagę zasługuje fakt, że podstawę analiz stanowią bardzo bogate i zróżnicowane dane językowe. Punkt wyjścia stanowią dane leksykograficzne, pochodzące ze słowników polszczyzny ogólnej. Szerszą perspektywę opisu przynoszą zaś dane tekstowe, m.in. materiały z Narodowego Korpusu Języka Polskiego. Uwzględnione zostały również wyniki badań własnych, m.in. ankiet przeprowadzonych wspólnie ze studentami pod kierunkiem Szadury. Dane te wzbogacone sa o bardzo interesujace materiały dialektologiczne, które ukazują bogaty obraz czasu, utrwalony w kulturze ludowej. Całość przedstawia się nad wyraz imponująco, ponieważ uzyskany w wyniku analiz obraz czasu jest wielowymiarowy i pełny.

\section{Podsumowanie}

Lektura książki Joanny Szadury to prawdziwa przygoda intelektualna. Autorka prowadzi wywód jasno i przejrzyście, dzięki czemu odsłaniają się przed czytelnikiem kolejne aspekty kategorii czasu. Temat, który podjęła, to zagadnienie uniwersalne $\mathrm{i}$ bardzo istotne dla wszystkich badaczy zajmujących się językiem i kulturą. Ponadto, jest to problem, z którym styka się każdy człowiek, zarówno doświadczając czasu psychologicznie czy somatycznie, jak i - żyjąc „w karbach” czasu zegarowego, który - jak słusznie zauważa autorka - staje się dziś dominującym modelem funkcjonowania współczesnych społeczeństw. Szeroka perspektywa poznawcza, ujęcie interdyscyplinarne, świadomość metodologiczna i wyjątkowo bogate dane materiałowe sprawiają, że nie można przecenić wartości tej publikacji. O żywym odbiorze książki i niewątpliwym uznaniu środowiska naukowego świadczy fakt, iż w 2018 roku autorka monografii została uhonorowana Nagroda Komitetu Językoznawstwa PAN za wybitne osiągnięcie naukowe w zakresie językoznawstwa.

DOROTA FILAR

Uniwersytet Marii Curie-Skłodowskiej w Lublinie

\section{Bibliografia:}

BARTMIŃSKI, J. (2001). O językowym obrazie świata Polaków końca XX wieku. W: S. Dubisz, S. Gajda (red.). Polszczyzna XX wieku. Ewolucja $i$ perspektywy rozwoju (s. 27-53).Warszawa: Dom Wydawniczy „Elipsa”,

BIELAWSKI, L. (1976). Strefowa teoria czasu $i$ jej znaczenie dla antropologii muzycznej, Kraków: Polskie Wydawnictwo Muzyczne.

SZADURA, J.(2017). Czas jako kategoria językowo-kulturowa $w$ polszczyźnie. Lublin: Wydawnictwo Uniwersytetu Marii CurieSkłodowskiej. 